ROCZNIKI NAUK PRAWNYCH

Tom LXXXI, numer 4 - 2021, s. 39-54

DOI: http://doi.org/10.18290/rnp21314-3

\title{
TYMON MARKIEWICZ
}

Katolicki Uniwersytet Lubelski Jana Pawła II tymon.markiewicz@kul.pl

ORCID: https://orcid.org/0000-0001-8362-5898

\section{SKARGA NA WYROK SĄDU ODWOŁAWCZEGO W ŚWIETLE ZASADY RZETELNEGO PROCESU Z ART. 6 EKPC*}

\author{
COMPLAINT AGAINST A JUDGMENT OF THE APPEAL COURT \\ IN THE LIGHT OF RULE OF TO A FAIR TRIAL UNDER ART. 6 ECHR
}

\begin{abstract}
The main purpose of this study is to present and evaluate institution of complaint against the cassatory judgment of the appeal court from the point of view of the right to a fair trial, provided for in Art. 6 (1) of the ECHR. The article presents arguments supporting the statement that Art. 6 (1) of the ECHR applies in complain proceeding, in the form of the standard of appeal and cassation proceedings, the possibility of applying this standard to a complaint, as well as the implementation of guarantees under Art. 6 (1) of the ECHR, with particular emphasis on the principle of equality of arms.
\end{abstract}

Keywords: Polish criminal procedure; complaint against the cassatory judgment of the appeal court; European Convention for Protection of Human Rights and Fundamental Freedoms; right to a fair trial.

\section{WPROWADZENIE}

Wprowadzenie w 2016 r. instytucji skargi na wyrok uchylający sądu odwoławczego $^{1}$ (rozdział 55a k.p.k. ${ }^{2}$ ) z założenia stanowiło domknięcie nowelizacji modelu postępowania odwoławczego w polskim procesie karnym ${ }^{3}$. Wynikało ono

* Tekst powstał w ramach grantu finansowanego ze środków Narodowego Centrum Nauki, konkurs OPUS 12, projekt nr 2016/23/B/HS5/03786, pt. „Skarga na wyrok sądu odwoławczego jako instrument przyspieszenia postępowania karnego i redukowania kasatoryjności”, realizowanego pod kierunkiem dr hab. Małgorzaty Wąsek-Wiaderek, prof. KUL.

${ }^{1}$ Art. 1 pkt 127 ustawy z dnia 11 marca 2016 r. o zmianie ustawy - Kodeks postępowania karnego oraz niektórych innych ustaw, Dz. U. 2016, poz. 437 ze zm.

${ }^{2}$ Ustawa z dnia 6 czerwca 1997 r. - Kodeks postępowania karnego, Dz. U. 2021, poz. 534 ze zm., dalej w tekście skrót: k.p.k.

${ }^{3}$ Zob. M. WĄSEK-WiadereK, A New Model of Appeal Proceedings in Criminal Cases: Accele- 
z uczynienia zasadą orzekanie merytoryczne, a więc w przypadku dostrzeżenia stosownych uchybień - reformatoryjne, przez sąd odwoławczy, a także istotnego zawężenia przesłanek orzekania kasatoryjnego, które zgodnie z art. 437 § 2 in fine k.p.k. możliwe jest wyłącznie w sytuacji wystąpienia bezwzględnej przyczyny odwoławczej z art. $439 \S 1$ k.p.k., reguły ne peius z art. $454 \S 1$ k.p.k. oraz konieczności powtórzenia na nowo przewodu w całości.

Wprowadzenie nowego środka zaskarżenia musi być postrzegane nie tylko na gruncie przepisów krajowych, ale także prawa międzynarodowego. Jako jeden $\mathrm{z}$ jego elementów należy wskazać art. $6 \mathrm{EKPC}^{4}$, statuujący prawo do rzetelnego procesu. Zgodnie $\mathrm{z}$ tym przepisem (art. 6 ust. 1 EKPC) każdy ma prawo do sprawiedliwego i publicznego rozpatrzenia jego sprawy w rozsądnym terminie przez niezawisły i bezstronny sąd ustanowiony ustawą przy rozstrzyganiu o jego prawach i obowiązkach o charakterze cywilnym albo o zasadności każdego oskarżenia w wytoczonej przeciwko niemu sprawie karnej ${ }^{5}$. Normatywne wprowadzenie, ale także już kilkuletnia praktyka, uwidacznia potrzebę analizy przepisów rozdziału 55a k.p.k. przez pryzmat art. 6 ust. 1 EKPC.

\section{STANDARD STRASBURSKI POSTĘPOWANIA ODWOLAWCZEGO I NADZWYCZAJNYCH ŚRODKÓW ZASKARŻENIA}

W ramach polskiego porządku prawnego skarga klasyfikowana jest jako nadzwyczajny środek zaskarżenia, jednakże bezpośrednio po wprowadzeniu do Kodeksu postępowania karnego przedmiotowych przepisów problem charakteru tego środka nie był w orzecznictwie rozstrzygany jednakowo. Sąd Najwyższy w sprawie VI KS $1 / 17^{6}$ uznał skargę wprost za zwyczajny środek odwoławczy (quasi-zażalenie), z kolei $\mathrm{w}$ sprawie VI KS $2 / 17^{7}$ zaliczono ją do kategorii nadzwyczajnych środków zaskarżenia. $Z$ kolei w piśmiennictwie zdecydowanie

ration v. Fairness? A Few Remarks from the Perspective of the Standards of Protecting Human Rights, „Studia Iuridica Lublinensia” 2020, nr 4, s. 187-207.

${ }^{4}$ Konwencja o Ochronie Praw Człowieka i Podstawowych Wolności z dnia 4 listopada 1950 r., Dz. U. 1993, nr 61, poz. 284 ze zm., w tekście: EKPC lub Konwencja.

${ }^{5}$ Zob. T. Barkhuysen, M. van Emmerick, O. Jansen, M. Fedorova, Right to a Fair Trial, [w:] Theory and Practice of the European Convention on Human Rights, red. P. van Dijk, F. van Hoof, A. van Rijn, L. Zwaak, Cambridge: Intersentia Publishing 2018, s. 497 n.; J. McBRIDge, Human Rights and Criminal Procedure, Strasburg: Council of Europe Publishing 2018, s. 305 n.; A. KLIP, European Criminal Law. An Integrative Approach, Cambridge: Intersentia Publishing 2021, s. 309 n.

${ }^{6}$ Zob. Postanowienie Sądu Najwyższego z dnia 21 kwietnia 2017 r., VI KS 1/17, LEX nr 2281284.

${ }^{7}$ Zob. Postanowienie Sądu Najwyższego z dnia 8 czerwca 2017 r., VI KS 2/17, LEX nr 2334903. 
przeważały stanowiska co do charakteru skargi jako nadzwyczajnego środka zaskarżenia, każdorazowo jednak powodowały konieczność szerszej argumentacji, co wskazuje na brak oczywistości prezentowanego poglądu ${ }^{8}$. Kluczowe znaczenie dla ostatecznego klasyfikowania skargi jako środka o charakterze nadzwyczajnym miały dwie uchwały Sądu Najwyższego: I KZP 9/17 ${ }^{9}$ i I KZP 13/17 ${ }^{10}$. Wskazano $\mathrm{w}$ nich, że ten charakter wynika m.in. $\mathrm{z}$ redakcyjnego umiejscowienia przepisów regulujących skargę w Dziale XI k.p.k. („Nadzwyczajne środki zaskarżenia”), $\mathrm{z}$ tego, że skarga przysługuje od wyroku prawomocnego ${ }^{11}$ oraz że postępowanie w przedmiocie skargi powinno być przede wszystkim sądem prawa, co do zasady oderwanym od rozstrzygania kwestii faktycznych ${ }^{12}$.

Należy jednak wskazać, że charakter skargi przyznany jej w ramach krajowego porządku prawnego jest irrelewantny $\mathrm{z}$ punktu widzenia art. 6 EKPC. W orzecznictwie Trybunału argumentuje się, że powoływany przepis Konwencji znajduje zastosowanie, gdy postępowanie, chociaż uznane w prawie krajowym za „nadzwyczajne” albo „wyjątkowe”, z natury i w swoim zakresie jest podobne do zwykłego postępowania odwoławczego ${ }^{13}$. Wypada tu podkreślić swoistą „ciągłość sprawy”, a więc sytuację, gdy nawet od wyroku prawomocnego przysługuje stronom środek zaskarżenia, mogący doprowadzić do wzruszenia zaskarżonego wyroku ${ }^{14}$. To właśnie w oparciu o to zastrzeżenie za rozpoznanie

${ }^{8}$ Zob. m.in. M. KLUBIŃSKA, Skarga na wyrok sądu odwoławczego jako środek zaskarżenia w postepowaniu karnym, „Ruch Prawniczy, Ekonomiczny i Socjologiczny” 2019, z. 3, s. 133-135; S. STEINBORn, Skarga na wyrok kasatoryjny sądu odwoławczego na tle systemu środków zaskarżenia w polskim procesie karnym, [w:] Verba volant, scripta manent. Proces karny, prawo karne skarbowe i prawo wykroczeń po zmianach z lat 2015-2016. Księga pamiątkowa poświęcona Profesor Monice Zbrojewskiej, red. T. Grzegorczyk, R. Olszewski, Warszawa: Wolters Kluwer 2017, s. 415 n.; D. GIL, Skarga na wyrok sądu odwoławczego jako nowy nadzwyczajny środek zaskarżenia w procesie karnym, „Ius et administratio” 2016, nr 3, s. 81-95.

${ }^{9}$ Uchwała Sądu Najwyższego z dnia 14 września 2017 r., I KZP 9/17, OSNKW 2017, nr 10, poz. 59.

${ }^{10}$ Uchwała Sądu Najwyższego z dnia 25 stycznia 2018 r., I KZP 13/17, OSNKW 2018, nr 3, poz. 23.

${ }^{11}$ Istnieje rozbieżność, czy wyrok uchylający i przekazujący sprawę do ponownego rozpoznania jest $\mathrm{w}$ pełni prawomocny czy jedynie prawomocny formalnie. Za pełną prawomocnością opowiadają się m.in. S. SteInBorn, Skarga na wyrok kasatoryjny, s. $415 \mathrm{n}$. Za prawomocnością formalną opowiadają się m.in. P. CZARNECKI, Skarga na wyrok sądu odwoławczego. (Non)sens nowego rozdziału 55a Kodeksu postępowania karnego?, „Czasopismo Prawa Karnego i Nauk Penalnych” 2016, z. 2, s. 94; J. ZAGRODNIK, Instytucja skargi na wyrok sqdu odwoławczego (rozdział 55a k.p.k.) - zarys problematyki, [w:] Verba volant, scripta manent, s. 523-524.

${ }^{12}$ Za postrzeganiem skargi na wyrok sądu odwoławczego jako środka powodującego kontrolę o charakterze formalnym zob. uchwała Sądu Najwyższego I KZP 13/17.

${ }^{13}$ Por. wyrok ETPC dnia 29 lipca 2004 r., San Leonard Band Club przeciwko Malcie, skarga nr 77562/01, § 41-48; wyrok Wielkiej Izby ETPC z dnia 5 lutego 2015 r., Bochan przeciwko Ukrainie (nr 2), skarga nr 22251/08, § 50.

${ }^{14}$ Por. P. HofmaŃSKI, Konwencja Europejska a prawo karne, Toruń: TNOiK 1995, s. 224. 
sprawy w ramach „oskarżenia w sprawie karnej” uznaje się m.in. polskie postępowanie kasacyjne ${ }^{15}$.

Standard konwencyjny postępowania odwoławczego i kasacyjnego należy uwzględniać w perspektywie przede wszystkim dwóch okoliczności: konieczności przeprowadzenia publicznej i ustnej rozprawy, a także obecności podsądnego na rozprawie ${ }^{16}$. Odnośnie do obu tych okoliczności nie występuje ich bezwzględna obligatoryjność.

W orzecznictwie Trybunału konsekwentnie funkcjonuje pogląd, zgodnie z którym istnieje możliwość odejścia od publicznej i ustnej rozprawy, jeżeli sąd rozpoznający środek zaskarżenia ma jedynie uprawnienie do kontroli wyroku pod względem prawnym i nie prowadzi postępowania dowodowego. Kluczowe w tej materii są orzeczenia zapadłe w sprawach: Axen przeciwko Republice Federalnej Niemiec ${ }^{17}$ i Sutter przeciwko Szwajcarii ${ }^{18}$. W drugiej z tych spraw Trybunał wprost stwierdził, że „brak jawnej rozprawy kasacyjnej nie narusza art. 6 ust. 1 EKPC, chodzi bowiem o rozprawę dotyczącą wyłącznie prawa”. Jednocześnie na etapie kasacyjnym art. 6 ust. 1 EKPC nie narusza także brak publicznego i jawnego ogłoszenia orzeczenia, a ewentualna konieczność dokonania tej czynności zależy od okoliczności konkretnej sprawy ${ }^{19}$. Można więc stanąć na stanowisku, że jawna powinna być rozprawa dotycząca faktów, w ramach której ma miejsce postępowanie dowodowe ${ }^{20}$.

Konieczność obecności podsądnego na rozprawie jest ściśle związana z wymogiem jej jawności i ustności. Oceniając możliwość odstępstwa od tej obecności, należy zasadniczo brać pod uwagę podobne kryteria jak w przypadku samej rozprawy, ze szczególnym jednak uwzględnieniem potrzeby osobistego zetknięcia się sądu z podsądnym, w szczególności w kontekście oceny jego depozycji procesowych $^{21}$. W orzecznictwie Trybunału wskazuje się, że w szeroko rozumianym postępowaniu odwoławczym udział oskarżonego $\mathrm{w}$ rozprawie nie jest aż

${ }^{15}$ Por. wyrok ETPC z dnia 18 października 2011 r., Dombrowski przeciwko Polsce, skarga nr 9566/10.

${ }^{16}$ Zob. M. WĄSEK-WIADEREK, Rzetelność postępowania odwolawczego $w$ polskiej procedurze karnej w świetle orzecznictwa Trybunatu Europejskiego, ,Prokuratura i Prawo” 1998, nr 11-12, s. 50 n.

${ }^{17}$ Por. wyrok ETPC z dnia 8 grudnia 1983 r., Axen przeciwko Republice Federalnej Niemiec, skarga $\mathrm{nr} 8273 / 78, \S 28$.

${ }^{18}$ Por. wyrok ETPC z dnia 2 lutego 1984 r., Sutter przeciwko Szwajcarii, skarga nr 8209/78, $\S 29-30$.

${ }^{19}$ Wyrok ETPC z dnia 17 grudnia 2013 r., Nikolova i Vandova przeciwko Bułgarii, skarga nr 20688/04, § 83-86.

${ }^{20}$ Zob. J. PRADEL, Rzetelny proces $w$ europejskim prawie karnym, „Prokuratura i Prawo” 1996, nr 9, s. 24.

${ }^{21}$ Por. wyrok ETPC z dnia 26 maja 1988 r., Ekbatani przeciwko Szwecji, skarga nr 10563/83, § 24; wyrok ETPC z dnia 29 października 1991 r., Fejde przeciwko Szwecji, skarga nr 12631/87, § 24. 
tak istotny jak w postępowaniu przed sądem pierwszej instancji ${ }^{22}$ i niekiedy możliwość naruszenia art. 6 ust. 1 EKPC jest badana właśnie przez pryzmat pełnej realizacji prawa do udziału w rozprawie przed sądem $a q u o^{23}$, zwłaszcza jeżeli odwoławczy etap postępowania dotyczy wyłącznie kwestii prawnych. W sprawie Helmers przeciwko Szwecji ${ }^{24}$ Trybunał uznał, że zgoda na wszczęcie postępowania apelacyjnego (leave to appeal proceedings) i postępowania ograniczonego do rozpoznawania wyłącznie kwestii prawnych mogą być zgodne $\mathrm{z}$ wymaganiami art. 6 EKPC, mimo że apelującemu nie dano możliwości wysłuchania go przez sąd apelacyjny lub sąd kasacyjny. W orzecznictwie Trybunału wskazuje się również, że w przypadku postępowania kasacyjnego za wystarczającą można uznać obecność profesjonalnego reprezentanta procesowego ${ }^{25}$.

Kolejnym istotnym elementem wynikającym z prawa do rzetelnego procesu jest zasada równości broni ${ }^{26}$. Nie jest ona literalnie zapisana w treści art. 6 ust. 1 EKPC, bezspornie jednak wynika z orzecznictwa Trybunału ${ }^{27}$. Próba definicji tej zasady została podjęta w sprawie Dombo Beheer B.V. przeciwko Holandii ${ }^{28}$, zgodnie z którą każda strona procesu musi mieć zapewnioną taką samą możliwość prezentowania swojej sprawy (także dowodów) w warunkach, które nie stawiają jej w sytuacji gorszej niż ta, w jakiej znajduje się oponent ${ }^{29} . \mathrm{Z}$ orzecznictwa Trybunału wynika, że omawiana zasada, pomimo pewnej specyfiki standardu rzetelnego postępowania odwoławczego i kasacyjnego, powinna być w peł-

${ }^{22}$ Por. wyrok ETPC z dnia 19 grudnia 1989 r., Kamasiński przeciwko Austrii, skarga nr 9783/ 82, § 106; wyrok Wielkiej Izby ETPC z dnia 2 listopada 2010 r., Sakhnovskiy przeciwko Rosji, skarga $\mathrm{nr} 21272 / 03, \S 98$.

${ }^{23}$ Por. wyrok Wielkiej Izby ETPC z dnia 11 lipca 2002 r., Göç przeciwko Turcji, skarga nr 36590/97, § 43-52.

${ }^{24}$ Por. wyrok ETPC z dnia 29 października 1991 r., Helmers przeciwko Szwecji, skarga nr $11826 / 85, \S 36$.

${ }^{25}$ Por. wyrok ETPC z dnia 8 lutego 2000 r., Josef Prinz przeciwko Austrii, skarga nr 23867/94, $\S 34$; wyrok Wielkiej Izby ETPC z dnia 26 lipca 2002 r., Meftah i inni przeciwko Francji, skargi nr 32911/96, 35227/97 i 24595/97, § 40.

${ }^{26}$ Zob. M. A. Nowicki, Wokót Konwencji Europejskiej. Komentarz do Europejskiej Konwencji Praw Człowieka, Warszawa: Wolters Kluwer 2017, s. 541-562.

${ }^{27}$ Por. wyrok ETPC z dnia 28 sierpnia 1991 r., Brandstetter przeciwko Austrii, skarga nr 11170/ 84, 12876/87 i 13468/87, § 66; wyrok ETPC z dnia 25 marca 1998 r., Belziuk przeciwko Polsce, skarga nr 23103/93, § 37; wyrok ETPC z dnia 18 marca 2014 r., Beraru przeciwko Rumunii, skarga nr 40107/04, § 70; wyrok Wielkiej Izby ETPC z dnia 13 września 2016 r., Ibrahim i inni przeciwko Wielkiej Brytanii, skargi nr 50541/08, 50571/08, 50573/08 i 40351/09, § 251.

${ }^{28}$ Por. wyrok ETPC z dnia 27 października 1993 r., Dombo Beheer B.V. przeciwko Holandii, skarga nr 14448/88, § 33 .

${ }^{29}$ Zob. S. Trechsel, Human Rights in Criminal Proceedings, Oxford: Oxford University Press 2005, s. 96-97; D. Duukić, The Right to Appeal in International Criminal Law, Leiden/Boston: Brill 2019, s. 53. 
ni respektowana również na tych etapach procesu. Pierwotnie można było dostrzec, że naruszenie zasady równości stron musiało być powiązane z konkretnym uchybieniem. W sprawie Delcourt przeciwko Belgii ${ }^{30}$ możliwość zajęcia stanowiska co do skargi kasacyjnej przez prokuratora przy jednoczesnej nieobecności skarżącego była jeszcze postrzegana przez pryzmat ustrojowej roli prokuratury, uznając jej funkcję za niezależną i bezstronną, mającą na celu poszanowanie praworządności, jednakże już w sprawie Borgers przeciwko Belgii ${ }^{31}$ zaakcentowano to, że zajęcie stanowiska przez prokuratora powoduje, iż staje się on przeciwnikiem procesowym swojego oponenta, co wymaga poszanowania zasady równości broni, a więc możliwości wypowiedzenia się podsądnego. $Z$ kolei już w sprawie Bulut przeciwko Austrii ${ }^{32}$ Trybunał wyraził jeszcze dalej idący pogląd, zgodnie z którym sam brak respektowania równości broni, nawet jeśli nie miał wpływu na wynik postępowania i nie wpłynął negatywnie na sytuację procesową oskarżonego, stanowi naruszenie zasady rzetelnego procesu.

Jak zostało wskazano powyżej, powyższy standard odnosi się do postępowania w przedmiocie kasacji, jednakże już nie do postępowania w przedmiocie wznowienia postępowania. Dotychczas w orzecznictwie Trybunału wskazywano, że brak zastosowania art. 6 EKPC do wznowienia postępowania ma wręcz rangę zasady $^{33}$, a ewentualna możliwość odejścia od niej pojawia się wyłącznie zupełnie wyjątkowo $^{34}$, jednakże w wyroku Wielkiej Izby z dnia 11 lipca 2017 r. $^{35}$ zostało zawarte stanowisko idące $\mathrm{w}$ kierunku odmiennym.

\section{MOŻLIWOŚĆ ZASTOSOWANIA STANDARDU STRASBURSKIEGO DO POSTĘPOWANIA W PRZEDMIOCIE SKARGI}

Mając na względzie powyższe rozważania i standard wypracowany w orzecznictwie Trybunału, należy podjąć próbę odpowiedzi na pytanie, czy art. 6 ust. 1 EKPC ma zastosowanie do postępowania w przedmiocie skargi na wyrok sądu

\footnotetext{
${ }^{30}$ Por. wyrok ETPC z dnia 17 stycznia 1970 r., Delcourt przeciwko Belgii, skarga nr 2689/65.

${ }^{31}$ Por. wyrok ETPC z dnia 30 października 1991 r., Borgers przeciwko Belgii, skarga nr 12005/ $86, \S 28$.

${ }_{32}$ Por. wyrok ETPC z dnia 22 lutego 1996 r., Bulut przeciwko Austrii, skarga nr 17358/90, § 49.

${ }^{33}$ Por. A. Wróbel, P. Hofmański, Komentarz do art. 6, [w:] Konwencja o Ochronie Praw Człowieka i Podstawowych Wolności. Tom I. Komentarz do artykułów 1-18, red. L. Garlicki, Warszawa: C.H. Beck 2010, nb. 90.

${ }^{34}$ Por. wyrok ETPC z dnia 29 lipca 2004 r., San Leonard Band Club przeciwko Malcie, skarga nr 77562/01, § 40-48.

${ }^{35}$ Por. wyrok Wielkiej Izby ETPC z dnia 11 lipca 2017 r., Moreira Fereira przeciwko Portugalii, skarga nr 19867/12.
} 
odwoławczego. Kluczowe jest tu ustalenie, czy postępowanie skargowe mieści się w pojęciu „oskarżenia w sprawie karnej” w rozumieniu art. 6 ust. 1 EKPC, innymi słowy, czy jest to postępowanie pozostające w głównym nurcie procesu, czy też jest postępowaniem incydentalnym, wpadkowym. W rzeczywistości ustalenie powyższego rozstrzyga zastosowanie konwencyjnego standardu rzetelności do przedmiotowego postępowania.

Zdaje się nie budzić wątpliwości, że postępowanie skargowe nie jest tylko postępowaniem toczącym się obok postępowania $\mathrm{w}$ przedmiocie odpowiedzialności karnej oskarżonego, ale jest jego pełnoprawnym elementem. Jest ono, co prawda, funkcjonalnie wyodrębnionym etapem, ale pozostającym w ścisłym związku z meritum sprawy. W pierwszej kolejności należy wskazać, że jest to postępowanie, które nie rozstrzyga ostatecznie o przedmiocie procesu, czyli odpowiedzialności karnej oskarżonego. W przypadku postępowania skargowego kwestia ta cały czas pozostaje otwarta. Niezależnie od proceduralnego podejścia do prawomocności wyroku kasatoryjnego, niewątpliwie nie jest to wyrok kończący postępowanie. Nie można tracić z pola widzenia, że zgodnie z art. 6 ust. 2 Konwencji, każdego oskarżonego o popełnienie czynu zagrożonego karą uważa się za niewinnego do czasu udowodnienia mu winy zgodnie z ustawą. Ustawą, o której traktuje Konwencja, w polskim porządku prawnym będzie art. 42 ust. 2 Konstytucji RP ${ }^{36}$, a także art. 5 § 1 k.p.k., gdzie unormowano zasadę domniemania niewinności. Tym samym wyrok kasatoryjny nie tylko nie kończy ostatecznie postępowania, ale prowadzi do jego ponownego przeprowadzenia, w którego ramach, niezależnie od przesłanki uchylenia wyroku, kwestia odpowiedzialności karnej oskarżonego pozostaje otwarta. Co istotne, zaskarżenie wyroku kasatoryjnego skargą, niezależnie od rozstrzygnięcia podjętego przez Sąd Najwyższy, zawsze prowadzić będzie do ponowienia postępowania. W przypadku, gdy Sąd Najwyższy skargę oddala, to sprawa trafia do ponownego postępowania przed sądem I instancji, albowiem oddalenie skargi oznacza niejako ,utrzymanie w mocy" wyroku kasatoryjnego. Z kolei w przypadku uwzględnienia skargi sprawa również będzie rozpoznawana na nowo, nie w postępowaniu jednak pierwszoinstancyjnym, ale odwoławczym. Powyższą argumentację wzmacnia to, że w przypadku wniesienia skargi możliwy jest wyłącznie jeden wniosek o uchylenie zaskarżonego wyroku i przekazanie sprawy do ponownego rozpoznania $^{37}$. Tym samym należy zauważyć, że rozstrzygnięcie $\mathrm{w}$ przedmiocie skargi

\footnotetext{
${ }^{36}$ Konstytucja Rzeczypospolitej Polskiej z dnia 2 kwietnia 1997 r., Dz. U. 1997, nr 78, poz. 483 ze zm., w tekście: Konstytucja RP.

${ }^{37}$ Zob. A. M. Tęcza-Paciorek, K. WróBlewski, Skarga na wyrok sadu odwoławczego, „Palestra" 2017, nr 9, s. 24-38.
} 
de facto wskazuje wyłącznie etap postępowania, w którego ramach sprawa ma być ponownie rozpoznawana.

Rozpoznanie skargi ma także bezpośredni wpływ na tok i wynik sprawy. Ten wpływ ukazuje się m.in. w związku ze wskazanym powyżej rozstrzygnięciem co do etapu, na który sprawa „wraca” po wydaniu wyroku kasatoryjnego. Jest to tym samym oczywisty wpływ na tok postępowania głównego $-\mathrm{z}$ jednej strony odmienne jest procedowanie na etapie pierwszoinstancyjnym, uwzględniając specyfikę postępowania po przekazaniu sprawy do ponownego rozpoznania, a inne w ramach postępowania odwoławczego, dodatkowo rozstrzygnięcie w przedmiocie skargi rzutuje na byt prawny jednego z kluczowych rozstrzygnięć zapadłych w toku procesu i powoduje albo uchylenie wyroku kasatoryjnego, albo „utrzymanie go w mocy”. Rozstrzygnięcie jednak w przedmiocie skargi ma także wpływ na wynik sprawy. Ten wpływ wynika również z podjęcia powyższej decyzji, ma jednak związek także z zakresem kognicji Sądu Najwyższego rozpoznającego skargę.

Po wprowadzeniu skargi do polskiego procesu karnego Sąd Najwyższy nie orzekał jednolicie, jak dalece może wnikać w sprawę, rozpoznając skargę, i jakiego rodzaju uchybienia jest uprawniony badać. Zgodnie z pierwszym z dwóch przeciwstawnych stanowisk Sąd Najwyższy nie był uprawniony do badania, czy zarzuty podniesione $\mathrm{w}$ apelacji są trafne i czy uchybienia zdiagnozowane przez sąd odwoławczy rzeczywiście wystąpiły, lecz tylko kontroluje, czy wobec stwierdzenia tych uchybień konieczne było uchylenie wyroku sądu pierwszej instancji $^{38}$. Odmienny pogląd prezentowany w orzecznictwie Sądu Najwyższego zakładał dopuszczalność badania w postępowaniu skargowym zasadności uwzględnienia zarzutów apelacji, o ile doprowadziło to do naruszenia art. $437 \S 2$ k.p.k., $\mathrm{w}$ zakresie zawartych $\mathrm{w}$ tym przepisie podstaw uchylenia kontrolowanego w trybie instancyjnym wyroku sądu pierwszej instancji i przekazania sprawy do ponownego rozpoznania ${ }^{39}$.

Zarysowana rozbieżność $\mathrm{w}$ orzecznictwie została rozstrzygnięcia uchwałą Sądu Najwyższego I KZP 13/17 $7^{40}$, zgodnie z tezą, której „zakres kontroli dokonywanej przez Sąd Najwyższy po wniesieniu skargi na wyrok sądu odwoławczego, o którym mowa w art. 539a § 1 k.p.k., ogranicza się do zbadania,

38 Por. postanowienie Sądu Najwyższego z dnia 9 grudnia 2016 r., IV KS 4/16, LEX nr 2165595; postanowienie Sądu Najwyższego z dnia 10 lutego 2017 r., IV KS 6/16, KZS 2017, nr 11, poz. 29.

${ }^{39}$ Por. wyrok Sądu Najwyższego z dnia 19 lipca 2017 r., V KS 7/17, LEX nr 2340622; wyrok Sądu Najwyższego z dnia 12 września 2017 r., III KS 6/17, niepubl.

${ }^{40}$ Uchwała Sądu Najwyższego z dnia 25 stycznia 2018 r., I KZP 13/17, OSNKW 2018, z. 3, poz. 23. 
czy stwierdzone przez sąd odwoławczy uchybienie daje podstawę do wydania orzeczenia kasatoryjnego". To stanowisko prowadzi do wniosku o formalnym charakterze skargi i sugeruje, że Sąd Najwyższy, rozpoznając ją, nie bada zarzutów apelacyjnych, a jedynie ogranicza się ściśle do kontroli wystąpienia przesłanek z art. 437 § 2 in fine k.p.k.

O ile sama powyższa koncepcja kognicji Sądu Najwyższego przy rozpoznaniu skargi zasługuje na aprobatę, należy jednak zauważyć, że postępowanie skargowe nie pozostaje w zupełnym oderwaniu od kwestii kontroli apelacyjnej dokonanej przez sąd odwoławczy, w tym także badania zarzutów apelacji. Jeżeli jednak Sąd Najwyższy sięga do tych zarzutów, to czyni to pośrednio, jedynie przez pryzmat naruszenia art. 437 § 2 k.p.k. Można wyobrazić sobie sytuację, gdy podstawą orzeczenia kasatoryjnego byłby np. brak bezpośredniego przesłuchania przed sądem I instancji kluczowego świadka, co byłoby także przedmiotem zarzutu. O ile potrzeba przeprowadzenia istotnego dowodu może mieścić się w ramach „konieczności powtórzenia na nowo przewodu w całości”, o tyle rozpoznając skargę Sąd Najwyższy powinien sprawdzić, czy rzeczywiście ten świadek nie został przesłuchany. Pośrednie wniknięcie w zarzuty apelacyjne może mieć miejsce także w przypadku uchylenia wyroku w związku z regułą ne peius z art. 454 $\S 1$ k.p.k. Możliwość uchylenia wyroku uniewinniającego, umarzającego postępowanie karne i przekazania sprawy do ponownego rozpoznania, związana $\mathrm{z}$ regułą ne peius, określoną w art. 454 § 1 k.p.k., zachodzi dopiero wtedy, gdy sąd odwoławczy - w wyniku usunięcia stwierdzonych uchybień, stanowiących jedną z podstaw odwoławczych określonych w art. 438 pkt 1-3 k.p.k. (czyli np. po uzupełnieniu postępowania dowodowego, dokonaniu prawidłowej oceny dowodów, poczynieniu prawidłowych ustaleń faktycznych) - stwierdza, że zachodzą podstawy do wydania wyroku skazującego, czemu stoi na przeszkodzie zakaz określony w art. $454 \S 1$ k.p.k. ${ }^{41}$ Niewątpliwie kluczowy dla możliwości uchylenia wyroku na tej podstawie jest przebieg postępowania odwoławczego i argumentacja o potrzebie skazania zawarta w uzasadnieniu wyroku kasatoryjnego, jednakże nie bez znaczenia mogą pozostawać w tym przypadku zarzuty postawione w apelacji na niekorzyść.

Należy mieć na względzie, że „oskarżenie w sprawie karnej” z art. 6 ust 1 EKPC ma znaczenie autonomiczne i obejmuje całość postępowania, łącznie z postępowaniem przygotowawczym ${ }^{42}$, procedurą odwoławczą i wymiarem kary ${ }^{43}$.

${ }^{41}$ Uchwała Sądu Najwyższego z dnia 20 września 2018 r., I KZP 10/18, OSNK 2018, z. 11, poz. 73 .

${ }^{42}$ Por. wyrok ETPC z dnia 24 listopada 1993 r., Imbrioscia przeciwko Szwajcarii, skarga nr 13972/88. 
Na gruncie tego pojęcia jako postępowania incydentalne, nieobjęte ochroną art. 6 ust. 1 EKPC, uznaje się m.in. spory związane ze stosowaniem ustawy amnestyjnej $^{44}$, postępowania $\mathrm{w}$ przedmiocie przyznania pomocy prawnej $\mathrm{w}$ sprawie karnej $^{45}$ czy postępowanie dotyczące reżimu więziennictwa ${ }^{46}$. Mając na względzie takie rozumienie postępowań wpadkowych, a także zastrzeżenie, że gwarancje proceduralne art. 6 EKPC muszą przysługiwać tak długo, jak długo zasadność wytoczonego oskarżenia w sprawie karnej nie zostanie ostatecznie rozstrzygnięta ${ }^{47}$, bacząc na bezwzględne powiązanie postępowania skargowego $\mathrm{z}$ postępowaniem w głównym nurcie procesu, należy wskazać, że postępowanie w przedmiocie skargi na wyrok sądu odwoławczego znajduje się pod ochroną art. 6 EKPC.

\section{POSTĘPOWANIE SKARGOWE A ZASADA RÓWNOŚCI BRONI}

Mając na względzie wniosek, że w postępowaniu skargowym znajdują zastosowanie gwarancje z art. 6 EKPC, należy odnieść się do ich rzeczywistej realizacji.

Zgodnie z art. 539e $\S 1$ k.p.k. Sąd Najwyższy rozpoznaje skargę na posiedzeniu bez udziału stron, a więc posiedzeniu niejawnym. Jak zostało wykazane w pierwszej części tekstu, nie jest to sytuacja, która sama przez się stanowiłaby naruszenie standardu strasburskiego. Wymogiem jest jednak charakter i przedmiot postępowania, skupienie się na kwestiach prawnych, a nie faktycznych. W przypadku skargi przeciwkasatoryjnej ważny jest zakres kognicji Sądu Najwyższego, statuujący kontrolę skargową jako formalną. Ponadto w orzecznictwie Sądu Najwyższego wyraźnie zarysowane są stanowiska, że odnoszenie się do kwestii faktycznych $\mathrm{w}$ sprawie nie mieści się $\mathrm{w}$ granicach postępowania skargowego - wskazano, że przepis art. 539a $\S 3$ k.p.k. nie przyznaje mu kompetencji do dokonywania oceny zebranego $\mathrm{w}$ sprawie materiału dowodowego ${ }^{48}$ oraz że poza istnieniem uchybienia określonego w art. $439 \S 1$ k.p.k. nie może

\footnotetext{
${ }^{43}$ Por. wyrok ETPC z dnia 5 lipca 1982 r., Eckle przeciwko Republice Federalnej Niemiec, skarga $\mathrm{nr} 8130 / 78$.

${ }^{44}$ Por. decyzja ETPC z dnia 13 maja 2003 r., Montcornet de Daumont przeciwko Francji, skarga nr 59290/00.

${ }^{45}$ Por. wyrok ETPC z dnia 12 czerwca 2003 r., Gutfreund przeciwko Francji, skarga nr 45681/ $99, \S 32$.

${ }^{46}$ Por. wyrok ETPC z dnia 15 września 2009 r., Enea przeciwko Włochom, skarga nr 74912/01, $\S 97$.

${ }^{47}$ Por. A. Wróbel, P. HofMAŃSKi, Komentarz do art. 6, nb. 63; por. również wyrok ETPC z dnia 23 września 1998 r., Malige przeciwko Francji, skarga nr 27812/95, § 34.

${ }^{48}$ Por. postanowienie Sądu Najwyższego z dnia 11 czerwca 2021 r., III KS 1/21, LEX nr 3191832.
} 
oceniać, czy zaistniały merytoryczne podstawy do wydania określonego wyroku ${ }^{49}$. W zakresie forum orzekania standard konwencyjny zostaje w postępowaniu skargowym zachowany.

Powyższa okoliczność nie jest jednak rozstrzygająca i należy zwrócić uwagę na respektowanie $\mathrm{w}$ ramach postępowania skargowego zasady równości broni. $\mathrm{Z}$ uwagi na rozpoznanie skargi na posiedzeniu niejawnym nie ma tu typowej dla postępowań kontradyktoryjnych ustnej wymiany argumentów i stanowisk. Nie oznacza to jednak, że równość broni nie jest zachowana.

Pierwszą płaszczyzną, na której można badać wskazaną równość, jest zakres podmiotowy prawa do wniesienia skargi. Zgodnie z art. 539a $\S 1$ k.p.k. skarga przysługuje stronom. Nie ma więc żadnego ograniczenia podmiotowego w zakresie możliwości wniesienia skargi i może to uczynić każda z nich. Jednocześnie wypada zauważyć, że zgodnie z art. $526 \S 2$ k.p.k. w związku z art. 539f k.p.k., jeżeli skarga nie pochodzi od prokuratora, musi być sporządzona i podpisana przez adwokata lub radcę prawnego, co ma zapewnić pewien poziom profesjonalizmu skargi i nie narusza art. 6 EKPC. Gwarancję stanowi tu także możliwość wyznaczenia obrońcy z urzędu wyłącznie do postępowania skargowego, tj. do sporządzenia i wniesienia skargi (art. $78 \S$ 1a k.p.k.). Należy także zaznaczyć, że przymus adwokacko-radcowski obowiązujący wobec skargi nie oznacza jednocześnie braku możliwości składania dalszych pism w toku postępowania skargowego osobiście przez strony.

Podstawowy jednak argument optujący za uznaniem, że w postępowaniu skargowym równość broni jest zachowana, wynika z możliwości wniesienia w terminie siedmiu dni od daty doręczenia skargi pisemnej odpowiedzi (art. 539c § 2 k.p.k.). W odniesieniu do odpowiedzi na skargę też zachowana jest równość podmiotowa, prawo to bowiem przysługuje każdej stronie, która skargi nie wniosła. Za ograniczenie zasady równości broni nie można uznać także terminowości odpowiedzi na skargę, albowiem wskazany w art. 539c $§ 2$ k.p.k. siedmiodniowy termin ma charakter instrukcyjny ${ }^{50} \mathrm{i}$ ewentualne uchybienie mu powoduje $\mathrm{w}$ rzeczywistości wyłącznie skutek w zakresie sądu, do którego należy kierować odpowiedź.

W orzecznictwie Trybunału wskazuje się, że postępowanie na etapie odwoławczym może mieć formę pisemną i nie narusza to standardu wyznaczonego przez art. 6 EKPC. Aby jednak dopuścić taką możliwość, wskazano warunki, do których należy zaliczyć odejście od rozstrzygania kwestii faktycznych

${ }^{49}$ Por. postanowienie Sądu Najwyższego z dnia 31 maja 2021 r., V KS 13/21, LEX nr 3181550.

${ }^{50}$ Por. A. SAKowicz, Komentarz do art. 539c, [w:] Kodeks postępowania karnego. Komentarz, red. A. Sakowicz, Legalis 2020, t. 3; D. ŚwIECKI, Komentarz do art. 539c [w:] Kodeks postępowania karnego. Tom II. Komentarz aktualizowany, red. D. Świecki, LEX/el 2021, t. 8. 
przy jednoczesnym umożliwieniu stronom złożenia pisemnych stanowisk, w których będą mogły wypowiedzieć się tak co do wniesionego środka zaskarżenia, jak $\mathrm{i}$ do dowodów skierowanych przeciwko nim ${ }^{51}$. Trybunał dopuszcza nawet pisemne postępowanie przed sądem pierwszej instancji, wyłącznie jednak w ramach zupełnego wyjątku i tylko w sprawach dotyczących drobnych czynów zabronionych ${ }^{52}$. Tym samym to właśnie normatywnie zagwarantowana możliwość wymiany pism prowadzi do wniosku, że w postępowaniu skargowym zasada równości broni zostaje zachowana.

Dodatkowym argumentem za zachowaniem zasady równości broni jest treść uzasadnienia orzeczenia zapadłego po rozpoznaniu skargi. Jak już zostało wskazane, niezależnie od tego, czy Sąd Najwyższy postanowieniem oddala skargę, czy też wyrokiem uchyla zaskarżony wyrok i przekazuje sprawę do ponownego rozpoznania w postępowaniu odwoławczym, sprawa każdorazowo trafia do postępowania ponownego. Wydając wyrok kasatoryjny, sąd odwoławczy w uzasadnieniu zawiera zapatrywania prawne i wskazania co do dalszego postępowania, które są dla sądu rozpoznającego sprawę ponownie wiążące (art. 442 § 3 k.p.k.), co stanowi wyjątek od zasady samodzielności jurysdykcyjnej sądu karnego ${ }^{53}$. Pomimo zastrzeżenia, że te zapatrywania i wskazania nie mogą dotyczyć oceny poszczególnych dowodów ${ }^{54}$, niewątpliwie wywierają one wpływ na wynik postępowania ponownego, rzutując na sytuację procesową stron. W postępowaniu skargowym, na podstawie art. 539f k.p.k., przepis art. $442 \S 3$ k.p.k. stosuje się odpowiednio. Wskazania jednak i zapatrywania Sądu Najwyższego nie są tożsame z tymi, które wydaje sąd odwoławczy. Skupiają się one bowiem wokół kwestii orzekania kasatoryjnego, a nie np. dalszego toku postępowania dowodowego. Tym samym te zapatrywania i wskazania nie powinny wpływać bezpośrednio na sytuację procesową stron postępowania, ewentualnie, z uwagi na decyzję co do etapu, na jakim będzie kontynuowane postępowanie, wpływają na tę sytuację w jednakowym stopniu.

${ }^{51}$ Por. wyrok ETPC z dnia 8 stycznia 2009 r., Schlumpf przeciwko Szwajcarii, skarga nr 29002/06, § 66-70.

${ }^{52}$ Por. decyzja ETPC z dnia 17 maja 2011 r., Suhadolc przeciwko Słowenii, skarga nr 57655/08.

${ }^{53}$ Por. S. ZABŁocki, Komentarz do art. 422, [w:] Kodeks postepowania karnego. Tom IV. Komentarz do art. 425-467, red. R. A. Stefański, S. Zabłocki, LEX/el 2021, t. 23 i orzecznictwo tam powołane.

${ }^{54}$ Por. wyrok Sądu Apelacyjnego w Katowicach z dnia 6 grudnia 2006 r., II AKa 213/06, KZS 2007, z. 5, poz. 73; wyrok Sądu Apelacyjnego w Białymstoku z dnia 11 lutego 2004 r., II AKa 397/03, OSAB 2004, z. 2, poz. 33. 


\section{RZETELNOŚĆ POSTĘPOWANIA}

\section{JAKO ELEMENT ZWIAZZANY Z POSTĘOWANIEM SKARGOWYM}

Norma art. 6 ust. 1 EKPC nazywana jest powszechnie ,prawem do rzetelnego procesu". Niezależnie od rozważań dotyczących stosowania art. 6 ust. 1 EKPC do postępowania w przedmiocie skargi rzetelność postępowania jest elementem nierozerwalnie związanym z tym postępowaniem, albowiem podlegającym badaniu w istotnej części spraw skargowych z uwagi na wykładnię pojęcia „konieczność powtórzenia na nowo przewodu w całości”, zawartego w art. $437 \S 2$ in fine k.p.k.

$\mathrm{Z}$ chwilą wprowadzenia zdekodowana $\mathrm{w}$ przywołanym przepisie przesłanka orzekania kasatoryjnego stanowiła nowe pojęcie prawne i była wykładana różnorako. Można było wyróżnić co najmniej dwa główne stanowiska: potrzeba ponowienia przewodu w całości zachodzi dopiero wtedy, gdy należy przed sądem pierwszej instancji przeprowadzić $\mathrm{w}$ całości postępowanie dowodowe ${ }^{55}$ albo powodem uchylenia przez sąd odwoławczy wyroku i przekazania sprawy do ponownego rozpoznania może być już konieczność ponowienia kluczowych, istotnych (a więc niekoniecznie wszystkich) dowodów w sprawie ${ }^{56}$.

Kwestię tę przesądził Sąd Najwyższy w uchwale w sprawie I KZP 3/19, gdzie w tezie orzeczenia wskazano, iż ,konieczność przeprowadzenia na nowo przewodu w całości, o której mowa w art. 437 § 2 zdanie drugie in fine k.p.k., jako powód uchylenia przez sąd odwoławczy zaskarżonego wyroku i przekazania sprawy sądowi pierwszej instancji do ponownego rozpoznania, zachodzi wówczas, gdy orzekający sąd pierwszej instancji naruszył przepisy prawa procesowego, co skutkowało, w realiach sprawy, nierzetelnością prowadzonego postępowania sądowego, uzasadniającą potrzebę powtórzenia (przeprowadzenia na nowo) wszystkich czynności procesowych składających się na przewód sądowy w sądzie pierwszej instancji” ${ }^{57}$. Powiązanie możliwości orzekania kasatoryjnego z rzetelnością postępowania jest poglądem trafnym, albowiem oddającym ratio legis przedmiotowej przesłanki. Należy bowiem wskazać, że obowiązek zapewnienia rzetelnego procesu karnego sprowadza się nie tylko do przestrzegania przepisów, które ustanowione zostały po to, aby wyinterpretowane $\mathrm{z}$ nich normy służyły

${ }^{55}$ Por. np. wyrok Sądu Najwyższego z dnia 15 marca 2018 r., sygn. akt II KS 4/18, LEX nr 2473786; wyrok Sądu Najwyższego z dnia 20 grudnia 2018 r., sygn. akt IV KS 29/18, LEX nr 2626308.

${ }^{56}$ Por. np. wyrok Sądu Najwyższego z dnia 21 listopada 2017 r., sygn. akt. III KS 8/17, LEX nr 2428758; wyrok Sądu Najwyższego z dnia 16 maja 2018 r., sygn. akt V KS 9/18, LEX nr 2500565.

${ }^{57}$ Uchwała Sądu Najwyższego z dnia 22 maja 2019 r., I KZP 3/19, OSNK 2019, nr 6, poz. 31. 
zapewnieniu gwarancji procesowych składających się na rzetelny proces karny. Stwierdzenie spełnienia wymogów rzetelności procesu sprowadza się do oceny realnego kształtu każdego konkretnego postępowania karnego. Tym samym na ocenę, czy dane postępowanie było rzetelne, wpływ ma nie tyle stwierdzenie określonego uchybienia procesowego, ile analiza przebiegu całego postępowania $^{58}$. M. Rogacka-Rzewnicka trafnie wskazuje, że postępowanie przed Trybunałem $\mathrm{w}$ przedmiocie naruszenia art. 6 ust. 1 EKPC przypomina trochę ,proces nad procesem", a nie tylko nad poszczególnymi elementami zaskarżonego rozstrzygnięcia. Nacisk na całokształt, globalny wynik procesu, jego prawną i aksjologiczną zgodność z konwencyjnym wymaganiem „rzetelności” pozwala osiągnąć perspektywę sprawiedliwości globalnej ${ }^{59}$. S. Zabłocki wskazuje, że ,zmaterializowanie się analizowanej tu przesłanki uzależnione będzie od specyficznej konfiguracji dowodów w każdej z rozpoznawanych spraw i oceniane casu ad casum ${ }^{60}$, co stanowi głos aprobujący za potrzebą każdorazowego odnoszenia konieczności ponowienia przewodu do realiów konkretnej sprawy i oceny pod tym kątem każdego postępowania, bez ustalania w tym zakresie sztywnych reguł.

Nie można więc zaakceptować sytuacji, w której Sąd Najwyższy miałby badać, czy przesłanka orzekania kasatoryjnego w postaci konieczności powtórzenia przewodu sądowego na nowo $\mathrm{w}$ całości została zrealizowana $\mathrm{w}$ związku $\mathrm{z}$ naruszeniem przepisów postępowania prowadzących do jednoczesnego naruszenia reguł rzetelności postępowania, w ramach postępowania, do którego nie odnosiłyby się te kryteria rzetelności.

\section{WNIOSKI}

W literaturze przedmiotu trafnie wskazuje się, że wprowadzenie do procesu karnego przedmiotowej skargi zachwiało systemem środków odwoławczych, który do tej pory dopuszczał wniesienie nadzwyczajnego środka zaskarżenia jedynie od orzeczenia prawomocnego, kończącego postępowanie ${ }^{61}$, $\mathrm{i}$ to także w kontekście przepisów prawa międzynarodowego.

\footnotetext{
${ }^{58}$ Por. wyrok Sądu Najwyższego z dnia 15 maja 2001 r., sygn. akt V KKN 79/01, Prok. i Pr. wkł. 2001, nr 10, poz. 8; postanowienie Sądu Najwyższego z dnia 5 marca 2019 r., sygn. akt IV KO 8/19, LEX nr 2629876.

${ }^{59}$ Por. M. Rogacka-Rzewnicka, Proces karny w perspektywie ewolucji naukowej $i$ wspótczesnych trendów rozwojowych, Warszawa: Wolters Kluwer 2021, s. 391.

${ }^{60}$ S. Zabłocki, Komentarz do art. 437, t. 24, pkt b).

${ }^{61}$ S. STAINBORN, Skarga na wyrok kasatoryjny, s. 415 n.
} 
Analiza standardu wypracowanego w orzecznictwie Trybunału dla postępowania odwoławczego i kasacyjnego, a także analiza postępowania skargowego pod kątem wskazanych tam kryteriów prowadzą do wniosku, że w postępowaniu w przedmiocie skargi na wyrok uchylający ma zastosowanie art. 6 EKPC. Postępowanie skargowe nie jest tylko postępowaniem incydentalnym, ale pozostaje w głównym nurcie procesu. Stanowi etap postępowania zmierzającego do finalnego rozstrzygnięcia o odpowiedzialności karnej oskarżonego, chociaż przedmiotem samego postępowania skargowego nie jest kwestia tej odpowiedzialności. Ze względu na to, że $\mathrm{w}$ tym postępowaniu nie przeprowadza się dowodów, nie czyni ustaleń faktycznych, a dotyczy ono wyłącznie kwestii prawnych, rozpoznanie skargi na posiedzeniu bez udziału stron nie narusza norm konwencyjnych, a gwarancje tego postępowania czynią zadość wymogom zasady równości broni.

\section{PIŚMIENNICTWO}

CzARneCKi Paweł: Skarga na wyrok sadu odwoławczego. (Non)sens nowego rozdziatu $55 a$ Kodeksu postępowania karnego?, „Czasopismo Prawa Karnego i Nauk Penalnych” 2016, z. 2, s. 77-105.

DJUKIĆ Dragan: The Right to Appeal in International Criminal Law, Leiden/Boston: Brill 2019.

Garlicki Lech (red.): Konwencja o Ochronie Praw Człowieka i Podstawowych Wolności. Tom I. Komentarz do artykułów 1-18, Warszawa: C.H. Beck 2010.

GIL Damian: Skarga na wyrok sąu odwoławczego jako nowy nadzwyczajny środek zaskarżenia w procesie karnym, „Ius et administratio” 2016, $\mathrm{nr} 3$, s. 81-95.

HofMAŃSKI Piotr: Konwencja Europejska a prawo karne, Toruń: TNOiK 1995.

Hofmański Piotr, Kulesza Cezary (red.): System prawa karnego procesowego Tom VI. Strony i inni uczestnicy postepowania karnego, Warszawa: Wolters Kluwer 2016.

KLIP André: European Criminal Law. An Integrative Approach, Cambridge: Intersentia Publishing 2021.

KLUBIŃSKA Maja: Skarga na wyrok sądu odwoławczego jako środek zaskarżenia $w$ postępowaniu karnym, „Ruch Prawniczy, Ekonomiczny i Socjologiczny” 2019, z. 3, s. 131-147.

McBridge Jeremy: Human Rights and Criminal Procedure, Strasburg: Council of Europe Publishing 2018.

Nowicki Marek Antoni: Wokót Konwencji Europejskiej. Komentarz do Europejskiej Konwencji Praw Człowieka, Warszawa: Wolters Kluwer 2017.

PRADEL Jean: Rzetelny proces w europejskim prawie karnym, „Prokuratura i Prawo” 1996, nr 9, s. 7-26.

Rogacka-Rzewnicka Maria: Proces karny w perspektywie ewolucji naukowej $i$ wspótczesnych trendów rozwojowych, Warszawa: Wolters Kluwer 2021.

SAKowicz Andrzej (red.): Kodeks postępowania karnego. Komentarz, Legalis 2020.

Stefański Ryszard Andrzej, ZabŁocki Stanisław (red.): Kodeks postępowania karnego. Tom IV. Komentarz do art. 425-467, LEX/el 2021. 
STEINBORN Sławomir: Skarga na wyrok kasatoryjny sądu odwoławczego na tle systemu środków zaskarżenia $w$ polskim procesie karnym, [w:] Verba volant, scripta manent. Proces karny, prawo karne skarbowe i prawo wykroczeń po zmianach z lat 2015-2016. Księga pamiątkowa poświęcona Profesor Monice Zbrojewskiej, red. T. Grzegorczyk, R. Olszewski, Warszawa: Wolters Kluwer 2017, s. 415-428.

ŚwIECKI Dariusz (red.): Kodeks postępowania karnego. Tom II. Komentarz aktualizowany, LEX/el 2021.

TęCZA-PACiorek Anna Marta, WróBlewski Krzysztof: Skarga na wyrok sądu odwoławczego, „Palestra” 2017, nr 9, s. 24-38.

Trechsel Stefan: Human Rights in Criminal Proceedings, Oxford: Oxford University Press 2005.

Van DiJk Pieter, van Hoof Fried, van Rijn Arjen, ZwaAk Leo (red.): Theory and Practice of the European Convention on Human Rights, Cambridge: Intersentia Publishing 2018.

Wąsek-Wiaderek Małgorzata: A New Model of Appeal Proceedings in Criminal Cases: Acceleration v. Fairness? A Few Remarks from the Perspective of the Standards of Protecting Human Rights, „Studia Iuridica Lublinensia” 2020, nr 4, s. 187-207.

WĄSEK-WIADEREK Małgorzata: Rzetelność postępowania odwoławczego w polskiej procedurze karnej w świetle orzecznictwa Trybunatu Europejskiego, „Prokuratura i Prawo” 1998, nr 11-12, s. 31-46.

ZAGRODNIK Jarosław: Instytucja skargi na wyrok sądu odwoławczego (rozdziat 55a k.p.k.) - zarys problematyki, [w:] Verba volant, scripta manent. Proces karny, prawo karne skarbowe i prawo wykroczeń po zmianach z lat 2015-2016. Księga pamiątkowa poświęcona Profesor Monice Zbrojewskiej, red. T. Grzegorczyk, R. Olszewski, Warszawa: Wolters Kluwer 2017, s. 519-535.

\section{SKARGA NA WYROK SĄDU ODWOŁAWCZEGO \\ W ŚWIETLE ZASADY RZETELNEGO PROCESU Z ART. 6 EKPC}

\section{Streszczenie}

W związku z wprowadzeniem w 2016 r. do polskiego procesu karnego instytucji skargi na wyrok sądu odwoławczego autor podejmuje analizę tej instytucji z punktu widzenia prawa do rzetelnego procesu, zawartego w art. 6 EKPC. Rozważania dotyczą kolejno standardu postępowania odwoławczego i kasacyjnego, możliwości zastosowania tego standardu do skargi, a także realizacji gwarancji wynikających z art. 6 EKPC, ze szczególnym uwzględnieniem zasady równości broni. W konkluzji autor staje na stanowisku, że w postępowaniu skargowym ma zastosowanie art. 6 EKPC.

Słowa kluczowe: polska procedura karna; skarga na wyrok kasatoryjny sądu odwoławczego; Europejska Konwencja o Ochronie Praw Człowieka i Podstawowych Wolności (EKPC); prawo do rzetelnego procesu. 